https://doi.org/10.26593/sentris.v2i1.4622.21-37

\title{
NATO in The Very Cold War: Why the US Needs NATO in the Arctic
}

\author{
Bernadeth Franchika ${ }^{1}$, Sharon Sebastian Effendy ${ }^{2}$, Vanessa Anthea ${ }^{3}$
}

${ }^{1}$ Faculty of Social and Political Sciences, Parahyangan Catholic University, Indonesia, bernadethfranchika@gmail.com

${ }^{2}$ Faculty of Social and Political Sciences, Parahyangan Catholic University, Indonesia, sbstn.sharon@gmail.com ${ }^{2}$ Faculty of Social and Political Sciences, Parahyangan Catholic University, Indonesia, nessaanthea@gmail.com

\begin{abstract}
Especially in the last few decades, the melting of sea ice within the Arctic have subsequently opened the possibility to explore and exploit the region. Previously seen as simply a region full of ice, the Arctic is believed to possess abundant natural resources, with an estimated $13 \%$ of undiscovered oil, $30 \%$ of natural gas resources in the world, as well as the opening of a new sea route which will be able to serve as a shortcut for countries to exchange goods - attracting states to pay closer attention to the region, be it militarily, politically, or economically, the United States being one of them. The increase in presence and power among Arctic and non-Arctic countries, especially Russia and China, has inarguably created a state of security dilemma among all parties involved, which is why if the US would like to seek a larger presence within the region, it becomes important for the country to involve NATO as one of its key partners, despite issues concerning the country and the organization especially ones regarding defense spending. For the purpose of this paper, the aforementioned argument will further be elaborated using Stephen M. Walt's concept of alliance formation and balance of power, supported by the concept of security dilemma.
\end{abstract}

Keywords: Arctic; NATO; United States; security dilemma; alliance formation

\begin{abstract}
ABSTRAK
Terutama dalam beberapa dekade terakhir, mencairnya es di wilayah Arktik telah membuka kemungkinan bagi berbagai pihak untuk melakukan eksplorasi dan eksploitasi kawasan tersebut. Wilayah yang sebelumnya hanya dipandang sebagai wilayah penuh es kini diyakini memiliki sumber daya alam yang berlimpah, dengan estimasi $13 \%$ minyak dan $30 \%$ gas alam di dunia, serta terbukanya jalur laut baru yang dapat berfungsi sebagai jalan pintas bagi perdagangan internasional - menarik perhatian berbagai negara untuk meningkatkan perhatiannya terhadap kawasan Arktik, baik dalam hal militer, politik, maupun ekonomi, Amerika Serikat menjadi salah satunya. Meningkatnya kehadiran dan kekuatan negara Arktik dan non-Arktik, terutama Rusia dan Tiongkok, kemudian menciptakan security dilemma atau dilema keamanan di antara pihak terlibat. Oleh karena itu, apabila AS hendak meningkatkan kekuatannya dan memiliki kehadiran yang lebih besar di Arktik, menjadi penting bagi AS untuk melibatkan NATO sebagai mitranya, terlepas dari masalah yang menyangkut kedua pihak, khususnya yang berkaitan dengan pengeluaran untuk pertahanan. Dalam tulisan ini, argumen tersebut akan dielaborasi lebih lanjut menggunakan konsep Stephen M. Walt terkait pembentukan aliansi dan keseimbangan kekuasaan, didukung oleh konsep dilema keamanan.
\end{abstract}

Kata Kunci: Arktik; NATO; Amerika Serikat; dilema keamanan, pembentukan aliansi

\section{Introduction}

Believed to be one of the regions with the most geostrategic importance due to its untapped natural resources, sea routes, and more, the Arctic attracts countries to increase their power within the 
region, including the United States. ${ }^{1}$ Being one of the Arctic countries and a member of the Arctic Council, the US is also especially interested in the region as its domestic policy towards Alaska is also part of its Arctic policy. The country has paid more attention to the Arctic since 2013 when the Obama administration released the National Strategy for the Arctic Region, emphasizing three lines of efforts, namely advancing the US' security interests, pursuing responsible Arctic region stewardship, and strengthening international cooperation. ${ }^{2} \mathrm{Up}$ until today, the US is seeking a larger presence in the Arctic to prepare for potential conflicts with other countries, especially to make up for its inactiveness within the region for the last few decades. ${ }^{3}$ In 2018, the US military is considered badly-equipped for polar missions, as it is still lacking a single major base, aircraft, and warships that are suitable for the region's low temperature. ${ }^{4}$ Since then, it has conducted numerous military training, deployed military troops and equipment to the region, and is building new icebreakers.

One of the most notable military partners of the US is the North Atlantic Treaty Organization (NATO). Relations between the US and the alliance, however, have not always been harmonic, especially due to the failure of several NATO members to meet the $2 \%$ requirement to share NATO's financial burden. This started in 2014 when all NATO members pledged to meet the $2 \%$ target in defense spending for the alliance by $2024 .{ }^{5}$ However, in 2019 , only 7 of the 29 NATO allies are able to reach the recommended spending target despite the boost of European countries' defense budgets. ${ }^{6}$ The failure has long been criticized by past presidents of the US but has further sparked anger and lambaste from President Trump, even describing them as "delinquent". In terms of defense expenditure, the US spends approximately US\$ 730 billion, being twelve times as much compared to the United Kingdom as the second country with the largest military spending among NATO countries. ${ }^{8}$

However, opposite to Trump, President Biden recently described the US' commitment to NATO as unshakeable, specifically stating "The United States is fully committed to our NATO alliance, and I welcome your growing investment in the military capabilities that enable our shared defenses. An attack on one is an attack on all. That is our unshakeable vow." That being said, the Biden administration indicates that the US, to a certain degree, still needs to maintain close relations with NATO. Therefore, the question arises: "Why does the US still need NATO even though it fails to meet the $2 \%$ requirement in defense spending?"

A lot of scholars believe that NATO is still maintained by the US even though it costs the US more than it does other members due to the interest of the US to spread liberalism and democracy in the world. NATO constantly promotes these values, which is also supported by the fact that 26 out of

\footnotetext{
${ }^{1}$ Donald L. Gautier, "U.S. Geological Survey Circum - Arctic Resource Appraisal," OTC Arctic Technology Conference (2011), https://doi.org/10.4043/22061-MS

${ }^{2}$ Donald L. Gautier, loc. cit.

${ }^{3}$ Christopher Woody, "The US Navy is learning how to operate in the Arctic, and more ships may not be the answer," Business Insider, February 7th, 2020, https://www.businessinsider.com/us-military-presence-in-arctic-challenged-by-harshconditions-2020-2? $\mathrm{r}=\mathrm{US} \& \mathrm{IR}=\mathrm{T}$

${ }^{4}$ Geoff Upton, "Great Power Problems: Russia Wants Control over the Arctic Region," The National Interest, April 25th, 2019, https://nationalinterest.org/feature/great-power-problems-russia-wants-control-over-arctic-region-54227

${ }^{5}$ Ryan Browne, "NATO report says only 7 members are meeting defense spending targets," CNN, March 14th, 2019, https://edition.cnn.com/2019/03/14/politics/nato-defense-spending-target/index.html ${ }^{6} \mathrm{Ibid}$.

${ }^{7}$ Niall McCarthy, "NATO Summit: The Countries Meeting The 2\% Threshold," Forbes, December 3rd, 2019, https://www.forbes.com/sites/niallmccarthy/2019/12/03/nato-summit-the-countries-meeting-the-2-thresholdinfographic/?sh=3e6c21161f2c

${ }^{8}$ Ibid.

9 "Biden says U.S. commitment to NATO is 'unshakeable'," Reuters, February 20th, 2021, https://www.reuters.com/article/us-g7-meeting-biden-munich-idUSKBN2AJ1ZT
} 
the 29 NATO members are considered "free" or has a certain degree of political rights ensurement for their citizens, according to indicators set up by the Freedom House.$^{10}$ Considered as one of the biggest achievements of US' history, the US government also stated that NATO will always matter because they promote democratic values and encourage trust as well as cooperation, which are also stated under the Washington Treaty, the foundation of NATO. ${ }^{11}$ Hence, it can be assumed that although financially the US is spending more than other countries in the organisation, NATO will always be relevant as one of the main purposes of the establishment of said organisation is to maintain and ensure the promotion of US' values and principles.

However, the writers of this paper believe that there are more concrete and contemporary factors that drive the US to still maintain their relations with NATO even if some countries fail to meet the $2 \%$ requirement. We believe that since several parties are starting to get eagerly and actively involved within the region, be it in terms of military or economy, which should raise concern and attention for the US to prepare an alliance to counterbalance said parties.

\section{Theoretical Framework}

Under the assumption of classical realists that self-interest is the main driving factor of any political behavior, power becomes the fundamental feature of politics. ${ }^{12}$ Hans Joachim Morgenthau once asserts that within matters of foreign policy, a state is considered to be a unitary actor and that its national interest becomes the key concept within the country's foreign policy itself. ${ }^{13}$ In this sense, the term is then defined as synonymous with power and it is believed that the best way to achieve it is through achieving its aims and maximizing one's power, be it military, economic, or political power.

For the purpose of this research, several concepts will be used to further elaborate and analyze the topic, which includes the concept of security dilemma, as well as Stephen Walt's alliance formation and balance of power.

\section{a. Security Dilemma}

Thomas Hobbes believes that according to realists, states were initially formed to anticipate the fear of humans in terms of competing with other humans. ${ }^{14}$ However, although the formation of states was initially intended to protect their people from external threats, the presence of fear now lingers in the international realm. In an anarchic international system, there is no higher power that exceeds the sovereignty of states. Due to this condition, it is understood that no international norm or organization has the power to overrule states, and hence, birther the notion of uncertainty. Kenneth Waltz, a neo-realist, believes that the anarchic system of international relations forces states to obtain as much power as possible. ${ }^{15}$ This understanding is rooted in the fact that states cannot predict what others might do in the

\footnotetext{
${ }^{10}$ David Wemer, "Here's Why the United States needs NATO," Atlantic Council (2018), https://www.atlanticcouncil.org/blogs/new-atlanticist/here-s-why-the-united-states-needs-nato/

11 "Why NATO Matters," U.S. Mission to the North Atlantic Organisation, https://nato.usmission.gov/our-relationship/whynato-matters/ (accessed on March 11th, 2021)

${ }^{12}$ Steve Smith, Amelia Hadfield, and Tim Dunne, Foreign Policy: Theories, Actors, Cases (Oxford: Oxford University Press, 2016), 32.

${ }^{13}$ Stefano Guzzini, Realism in International Relations and International Political Economy (London: Routledge, 1998).

${ }^{14}$ Robert Jackson and Georg Sorensen, Introduction to International Relations: Theories and Approaches (United Kingdom: Oxford University Press, 2013), 71.

${ }^{15}$ Ibid.
} 
future. As states cannot trust each other, it is better to ensure their survivability by increasing their power. ${ }^{16}$

The presence of uncertainty birthed a security dilemma in the international realm. The concept of security dilemma assumes that most steps taken by a great power to enhance its security will subsequently decrease that of other states. ${ }^{17}$ In that sense, it is considered difficult for a state to improve its power without threatening other states. Feeling threatened, the opposed state then will do whatever necessary to ensure their own survival to be able to maintain its national interests which in turn will threaten other states as well and will then lead to what is called a security competition.

In this research, the theory of uncertainty will be used to examine the status quo of the Arctic, especially in regards to how states interact with each other. The concept of security dilemma will be used to understand the tension within the Arctic as a consequence of the increasing militarisation of parties within the region. The research will specifically discuss the rising security dilemma between the US and other major parties that evolved as each state is constantly pursuing its national interests.

\section{b. Alliance formation and the Balance of Power}

Averting the source of external threat is the key aim of states in an anarchical international order. ${ }^{18}$ Once states realize that they cannot materialize its national security on their own, they form alliances in an attempt to add to their capabilities and those of their allies to minimize the threat. ${ }^{19}$ An alliance is a 'formal or informal cooperative agreement between two or more states intended to further the national security of the participating states.' This implies that states seek alliances when they are under a threat, and in need of security to balance them. Thus, not the balance of power, as claimed by classical realists, but the balance of threat better explains alliance formations. ${ }^{20}$

The level of threat that states could have is not just based solely on the distribution of power. Stephen M. Walt points out four factors affecting a state's attribution to a threatening situation, which are: (1) Aggregate power that could be seen through its population, industrial and military capabilities. The greater a state's potential to threaten others in a form of foreign influence and political penetration; (2) Proximate Power which explained responses towards threats based on distances; (3) Offensive Capability; and (4) Offensive Intentions. ${ }^{21}$

This paper aims to highlight the role of Russia and China as a source of threat and security dilemma in the Arctic, specifically towards the United States. This will subsequently lead to support the writers' main argument of why the formation of alliance becomes paramount for the US within the region, which in this case specifically refers to the NATO Alliance.

\section{Analysis}

\footnotetext{
${ }^{16}$ Christopher W. Hughes and Lai Yew Ming, Security Studies: A Reader (New York: Routledge, 2011), 205.

${ }^{17}$ Tim Dunne, Milja Kurki and Steve Smith, International Relations Theories (USA: Oxford University Press, 2013 ), 80.

${ }^{18}$ Dogachan Dagi, "Balance of Power of Balance of Threats: Revisiting Ottoman Alliance Politics before the Great War," Open Political Sciences (2018): 144.

${ }^{19}$ K. N. Waltz, Theory of International Politics (Reading, Mass. 1979), 126.

${ }^{20}$ Dogachan Dagi, loc. cit.

${ }^{21}$ Stephen M Walt, “Alliance Formation and the Balance of World Power," International Security 9 no. 4 (1985): 9
} 
To elaborate further on the writers' argument as to why the US still needs NATO in the Arctic region despite failing to meet the $2 \%$ requirement in defense spending, the analysis will be divided into four parts, which are the status quo of the Arctic, Moscow's militarization of the Arctic, the presence of Beijing within the Arctic, and finally, the importance of NATO itself for the US in the Arctic region - all supported by the concepts explained within the theoretical framework section of this paper.

\section{a. Status Quo of the Arctic and US' Interests}

Tension amongst countries within the Arctic has continuously been escalating, as the region contains an abundance of untapped natural resources reserves that is attractive for all parties involved. There are currently eight countries that have territorial claims within the region, which are the US, Russia, Canada, Sweden, Denmark, Finland, Norway, and Iceland. ${ }^{22}$ The melting of ice within the region has resulted in assertive measures taken by the eight states in consolidating their claims and pursuing their national interests. However, due to uncertainty and overlapping claims between each country, militarization is one of the major measures taken by each party in ensuring their position within the region.

The US has declared their interests since 1994, in a Presidential Decision Directive mentioned four core interests of the US in the Arctic: $:^{23}$

1. Protecting the relatively unspoiled environment of Antarctica and its associated ecosystems;

2. Preserving and pursuing unique opportunities for scientific research to understand Antarctica and global physical and environmental systems;

3. Maintaining Antarctica as an area of international cooperation reserved exclusively for peaceful purposes; and

4. Ensuring the conservation and sustainable management of the living resources in the oceans surrounding Antarctica.

Generally, it can be understood that the US does not approve of other powers, especially those that are non-Western, to exploit and make use of the resources of the Arctic. Furthermore, the untapped natural resources that have been more accessible in the 2010s make the region more economically attractive. Despite being rather inactive in the last few decades, the aforementioned interests followed by a more accessible Arctic has led the US to pursue a more active policy within the region. The clash of interests of the US and other states in the region has developed into tension and insecurity.

Although several disputes, such as one between Norway and Russia back in 2010, have been settled, most of them are still currently taking place, including overlapping claims between Canada and Denmark, Canada and the US, as well as one between Canada, Denmark, and Russia in several territories. ${ }^{24}$ These disputes are expected to be resolved under the United Nations Convention of the Law of the Sea (UNCLOS). However, as there are even more at stake (such as the opportunity to exploit natural resources and accessibility of several new routes) due to the worsening climate change,

\footnotetext{
${ }^{22}$ Sophie des Beauvais, "Map Room Arctic Militarization,” World Policy, http://worldpolicy.org/wpcontent/uploads/2015/06/Summer15 16-17 MapRoom.pdf (accessed on February 11th, 2021)

${ }^{23}$ Committee on the Assessment of U.S. Coast Guard Polar Icebreaker Roles and Future Needs. Polar Icebreakers in a Changing World: An Assessment of U.S. Needs. (Washington: The National Academies Press, 2007). Url: https://www.nap.edu/read/11753/chapter/5\#21

${ }^{24}$ Wilfrid Greaves, "Thinking Critically About Security and the Arctic in the Anthropocene," The Arctic Institute, March 22nd, 2016, https://www.thearcticinstitute.org/thinking-critically-security-arctic-anthropocene/
} 
states are more willing to defend their national interests, even if it requires them to take more assertive measures that might lead to an open armed conflict with other states.

For example, Russia, under the presidency of Vladimir Putin, has stated that the Arctic is going to be developed to support Russia's economic isolation due to the Western sanctions over the Crimea issue back in 2014. ${ }^{25}$ Hence, previously abandoned military installations since the Cold War has been reopened to secure their position in the region. Due to the uncertain nature of states' behavior, the seemingly aggressive action is seen as a threat to other Arctic nations, which then believe that they too should increase their military presence. Furthermore, China, which is not an Arctic country nor a claimant within the territory has also sought to promote its economic interests within the region. This notion is translated through their plan to build a nuclear-powered icebreaker to be placed within the Arctic, as well as developing an Ice Silk Road plan to support international trade. ${ }^{26}$ The increasing presence of the non-Western countries is causing distress to other states and eventually forcing every party involved to step up their game.

Currently, there have not been developed any comprehensive systems to resolve disputes, except several frameworks under UNCLOS. Nevertheless, since one of the major parties, which is the US, has yet to ratify the convention, any dispute settlement mechanism used under said international law might be difficult to pursue. Furthermore, several plans to develop cooperative mechanisms between states within the territory have emerged under the Arctic Council to ensure the stability of the region. ${ }^{27}$ However, the Arctic Council also has limitations to establish documents related to military security. Uncertainty within the Arctic has also made it less likely for states to follow through with any established agreements, or at least they are going to take every measure possible to ensure their national interests are maintained.

\section{b. Threat of Non-Western Countries}

\section{Moscow's Presence in the Arctic}

Besides the US, one of the major players whose power is constantly escalating within the Arctic is Russia. Considering the two countries' history, it can be assumed that the US and Russia might be threatening each other within the region. However, before further analysis is presented in regards to the present tension between the two countries, we must first understand Russia's goals in the Arctic that are elaborated in the Arctic to 2020 and Beyond document that was presented in 2008 .

There are four national interests of Russia in the Arctic, which includes: the use of the region as a strategic resource base, maintenance of the region as a zone of cooperation, preservation of unique ecological systems of the Arctic, and the use of the region as a strategic sea route. ${ }^{28}$ Just like other countries, Russia has a deep interest in the vast natural resources obtained within the Arctic, as it is estimated that the region has up to 90 billion barrels of oil, 44 billion

\footnotetext{
${ }^{25}$ Marc Lanteigne, "The Changing Shape or Arctic Security," NATO Review, June 28th, 2019.

https://www.nato.int/docu/review/articles/2019/06/28/the-changing-shape-of-arctic-security/index.html

${ }^{26}$ Marc Lanteigne, "The Changing Shape or Arctic Security," NATO Review, loc. cit.

${ }^{27}$ Pinar Akcayoz De Neve et al. "Security of the Arctic," Belfer Center for Science and International Affairs (2015), https://www.belfercenter.org/sites/default/files/legacy/files/Arctic\%20Security\%20Policy\%20Brief.pdf

28 “Russian Federation's Policy for the Arctic to 2020," KOARC, September 18th, 2008.

http://koarc.org/theme/northpn_ko/03/pdf/rusia_eng.pdf
} 
barrels of natural gas liquids, and 1669 trillion cubic feet of natural gas. ${ }^{29}$ Aside from the tremendous mineral reserves, the Arctic also contains abundant bio-resources, including several fish species that are important for Russian commercial fishing. ${ }^{30}$ Due to this fact, it is understandable that Russia, alongside every other country, have very strong national interests within the region. Furthermore, as the global temperature continuously arises, the ice in the Arctic is melting. This means that the potential of the discovery of even more natural resources that are currently still frozen is very likely to happen in the future. The melting of ice also opens up the Northern Sea Route (NSR) which will benefit Russia, especially in terms of transport communication. ${ }^{31}$

Due to these reasons, Russia has taken aggressive measures to increase its presence within the Arctic. Since 2007, Russia continuously increases their military activities, especially in the air and waters of the Arctic, as the country is implementing a determined naval modernization program. ${ }^{32}$ For instance, in late 2020, Russian President, Putin, attended a ceremony of the deployment of a formidable ice-breaker that is nuclear powered, Arktika. ${ }^{33}$ This is done just two weeks before the presidential election. Russia's dominance is constantly increased, especially due to the fact that no other country produces nuclear-powered icebreakers, and Arktika is Russia's third, with Sibir and Ural already launched earlier. ${ }^{34}$ Hence, it can be understood that other countries, including the US are paying close attention to Russia's increasing assertiveness within the Arctic.

In regards to this, a certain degree of competition can be observed as the security dilemma within the region rises, as the US also has several national interests within the Arctic, which also include the reserves of the natural resources within the region. Furthermore, the US wishes to define the NSR, a route that is claimed by Russia, as international. ${ }^{35}$ If this idea is achieved, the circumstances will ultimately cost Russia the privilege of exclusive use of the route, significant revenue from other countries using said route, and security vulnerability from the North. Thus, the notion of security dilemma plays a role in these circumstances, in which Russia and the US both feel like the other party is going to jeopardize their national interests within the Arctic. If the US was to obtain their national interest to exploit the natural resources of the Arctic and define the NSR as international, Russia's interests will be compromised. Hence, it can be understood that Russia's aggressive behavior that includes militarisation, as well as the deployment of the world's strongest and only icebreakers that are nuclear powered might not necessarily be an act of offensive nature, but rather a defensive one aimed to protect their claims.

Furthermore, the presence of a security dilemma is also reflected in official statements from state officials. For example, Russian defense commentator, Alexandr Golts, stated that the confrontational approach of Moscow is conducted as a response to other Arctic nations' willingness to use force that is shown through the US and Canada's activities that often includes

\footnotetext{
${ }^{29}$ Lassi Heininen et al. "Russian Strategies in the Arctic: Avoiding a New Cold War," Valdai Discussion Club (2014), https://www.uarctic.org/media/857300/arctic_eng.pdf 
military exercises in the Arctic region. ${ }^{36} \mathrm{He}$ mentioned that as other countries are showing readiness to face military conflicts, Russia should also prepare itself. However, Hillary Clinton, who was the US' Secretary of State at the time, mentioned that the measures taken by the US in the arctic were never intended to threaten Russia, but rather was targeted to counter the missile threat from North Korea. ${ }^{37}$

This supports the notion that the measures taken by Russia are not necessarily intended to threaten the US' position, but the increase of defensive mechanisms is seen as offensive by the US. This creates a security dilemma in which both the US and Russia constantly increases their power to counter the other. Hence, it can be concluded that Russia's presence is one of the main concerns of the US in pursuing their national interests in the Arctic.

\section{Beijing's Presence in the Arctic}

Other than Russia, the People's Republic of China (PRC), one of the Arctic Council's permanent observers, has also increasingly been intensifying its presence within the region. In 2018, China published its white paper titled "China's Arctic Policy" as the first formulation of an official Chinese Arctic policy. ${ }^{38}$

Within the paper, China describes itself as a "near-Arctic country" geographically as it is one of the continental states that are closest to the Arctic Circle, specifically stating that the conditions happening in the Arctic will directly impact China's environment, climate, and subsequently its economic interests. ${ }^{39}$ Through the policies and positions on participating in Arctic affairs outlined within the paper, China shows its interest in developing shipping routes, exploring and exploiting oil, gas, mineral, and other non-living creatures, conserving and utilizing fisheries and living resources, as well as developing tourism resources throughout the region. ${ }^{40}$ Moreover, the white paper also outlined China's intent on creating a "Polar Silk Road" (PSR) to facilitate connectivity and sustainable economic and social development of the Arctic as part of its Belt and Road Initiative. ${ }^{41}$

That being said, China's interest in the Arctic is evident, that is access to Arctic natural resources and use of its shipping routes, including the NSR which is believed to be a shortcut of approximately over 4,600 km shorter from Shanghai to German ports, in comparison to the traditional route via the Suez Canal. ${ }^{42}$ The Polar Silk Road (PSR) will also serve as a shipping route connecting three major economic centers - North America, East Asia, and Western Europe and will offer China channels to explore energy resources within the region, which all will be beneficial for China when fully operational. ${ }^{43}$

\footnotetext{
${ }^{36}$ Aleksandr Golts, "The Arctic: A Clash of Interests or Clash of Ambitions?" in Russia in the Arctic, ed. Stephen J. Blank, (Carlisle, Pa.: Strategic Studies Institute, U.S. Army War College, 2011), 59.

${ }^{37}$ Jackie Northam, "Clinton, Russia Spar Over Missile Defense System,” NPR, December 8th, 2011, http://www.npr.org/2011/12/08/143386914/clinton-russia-spar-over-missile-defense-system.

${ }^{38}$ Trym Aleksander Eiterjord, "China's Busy Year in the Arctic," The Diplomat, January 30th, 2019, https://thediplomat.com/2019/01/chinas-busy-year-in-the-arctic/

39 "China's Arctic Policy," The State Council Information Office of the People's Republic of China, January 26th, 2018, http://english.www.gov.cn/archive/white_paper/2018/01/26/content_281476026660336.htm

40 Ibid.

${ }^{41}$ Ibid.

${ }^{42}$ Marisa Lino, "Understanding China’s Arctic activities," IISS, February 25th, 2020, https://www.iiss.org/blogs/analysis/2020/02/china-arctic

${ }^{43}$ Liu Caiyu, "China's role in Arctic governance cannot be ignored," Global Times, November 22nd, 2018, https://www.globaltimes.cn/content/1128626.shtml
} 
Since then, China has succeeded to execute most of its interests and intentions laid out in the paper into reality. In the last months of 2018, the country also launched The Xuelong 2, its first domestically built polar icebreaker, which significantly will boost China's polar research and expedition capabilities. ${ }^{44}$ Chinese shipping activities within the region have also increased, some originating and terminating at ports in Europe, due to China's new ice-capable cargo vessels. ${ }^{45}$ It is also known that China is currently building another nuclear-powered icebreaker. ${ }^{46}$ Moreover, it is reported that China is investing heavily in various and numerous projects in nearly every Arctic country, such as the billion-dollar Yamal LNG project investment to extract energy sources from the permafrost on the Yamal Peninsula of Northern Russia. ${ }^{47}$ Having just started on its PSR project and its Arctic policy, China is believed to have more in store for the region, including the potential investment on an Arctic Corridor railway connection between Kirkenes in Norway and Rovaniemi in Finland, which is theoretically linked to Russian, Chinese, and other European rail lines. $^{48}$

China's increasing presence and prominence within the Arctic region have then raised several concerns from Arctic states in regards to its long-term strategic objectives, including and especially regarding the possibility of military deployment. The aforementioned increasing presence, added by the close cooperation between China and Russia as one of its biggest rivals will undeniably create a condition of security dilemma for the United States. This condition is also worse keeping in mind that the US has been relatively inactive in the Arctic for the last few decades. China being viewed as a threat by the US in the Arctic is shown through the 2019 update made to its Arctic strategy, specifically stating that "China is attempting to gain a role in the Arctic in ways that may undermine international rules and norms, and there is a risk that its predatory economic behavior globally may be repeated in the Arctic". 49

The security dilemma, which emerged out of the condition of uncertainty, is then compounded by the deepening of great power competition within the region. Within the same strategy, the US described its strategy for the Arctic region "in an era of strategic competition," indicating that the strategy is updated for the US to compete against the great powers present in the region, namely China and Russia. Also, US Secretary of State Mike Pompeo in 2019 also stated, "The Arctic has become a region for power and competition ... We are entering a new age of strategic engagement in the Arctic", reflecting how the US views the Arctic as an arena for great power rivalry. ${ }^{51}$ In this sense, it can be inferred that to a certain degree, the US feels threatened by the increasing presence of China as one of its biggest rivals in the Arctic region, fearing that the country would dominate or take over said area which is a matter of interest for the US.

The established security dilemma will certainly spark concern and fuel attention for the US to escalate its presence throughout the Arctic region, be it diplomatically, militarily, or

\footnotetext{
${ }^{44}$ Franz-Stefan Gady, "China Launches First Domestically Built Polar Icebreaker," The Diplomat, September 11th, 2018, https://thediplomat.com/2018/09/china-launches-first-domestically-built-polar-icebreaker/

${ }^{45}$ Trym Aleksander Eiterjord, loc. cit.

${ }^{46}$ Ibid.

${ }^{47}$ Marisa Lino, loc. cit.

${ }^{48}$ Marc Lanteigne, "The Twists and Turns of the Polar Silk Road," Over the Circle, March 15th, 2020,

https://overthecircle.com/2020/03/15/the-twists-and-turns-of-the-polar-silk-road/

${ }^{49}$ Camilla Sørensen, "Intensifying U.S.-China security dilemma dynamics play out in the Arctic: Implications for China's

Arctic strategy," Arctic Yearbook (2019): 2.

${ }^{50}$ Ibid.

${ }^{51}$ Camilla Sørensen, loc. cit.
} 
economically. This is proved by the upgrade in the US diplomatic approach towards the Arctic, shown in the increase of high-level visits to the region and the reopening of a permanent US diplomatic outpost in Greenland. ${ }^{52}$ Therefore, it becomes important for the United States to continue to pay more attention to the Arctic, especially if they are trying to restrain Russian and Chinese influence throughout the region.

\section{c. Alliance Formation and Balance of Power in the Arctic through NATO}

As a result of the different approaches and strategies, as well as the proximity of their military deployments in the region, both the US and Russia view each other as destabilizing and often misinterpret each other's actions and intentions in the Arctic. As one of the most influential states and its rival in the Arctic, the increasing military capabilities of Russia can subsequently be seen as a threat to the US. According to alliance formations theories, Walt pointed out four factors that could put states in a threatening situation. The first one is the aggregate power of a state, in which the greater a state's potential to threaten others in a form of foreign influence and political penetration. In this theory, the power of the state is measured based on its total resources that could be seen through its population, industrial and military capabilities, even technological powers.

As to what has been mentioned in the previous section, Russia's aggregate power can be identified as its influence and reputation in the international realm based on its military capability in the Arctic. These advantages are seen by the US as a possibility for Russia to be more influential in the Arctic region, meaning that Russia has the potential to influence political decision-making or rules for the region. Not to forget, Russia's aggregate power is supported by its advantages from the second factor, which is geographical proximity. The US region in the Arctic is both smaller and less populated compared to the other Arctic Coastal States, including Russia. The largest communities ruled by the US are in North Alaska, with approximately 3,000 to 4,000 inhabitants, most of them living in the towns of Kotzebue and Barrow. In comparison to its rival which is categorized as the largest community in the Arctic, Russia has approximately 325,000 inhabitants. ${ }^{53}$

Russia's geographical proximity that is larger than the US can be considered as an additional threat to the US's presence in the Arctic, in terms of the land-owned and its populations. This is due to the fact that these geographical measurements will make it easier and quicker for Russia to access the Arctic rather than the US. These advantages of the aggregate power and geographical proximity are intertwined with Russia's offensive power and capacity - the third factor. Russia's militarisation and deployment of the world's strongest and only nuclear-powered icebreakers may not necessarily be intended to threaten the US' position, but the US may interpret Russia's decision to increase its defensive mechanisms is seen as an offensive action.

The last factor is offensive intentions, which can be seen through the expansion of China's economy that is supported by Russia in the Arctic. Also mentioned in the previous section, the 2019 statement coming from US Secretary of State Mike Pompeo can be inferred that the US feels threatened and/or challenged by the increasing and aggressive presence of China in the Arctic. ${ }^{54}$ Even though it currently does not possess sustained military assets, Chinese scientific or economic activities

\footnotetext{
${ }^{52}$ Sarah Cammarata, "U.S. reopens consulate in Greenland amid White House's Arctic push," Politico, October 6th, 2020, https://www.politico.com/news/2020/06/10/us-reopens-greenland-consulate-310885

${ }^{53}$ Heather A Conley, “A New Security Architecture for the Arctic: An American Perspective," CSIS (2012), https://csiswebsite-prod.s3.amazonaws.com/s3fs-public/legacy_files/files/publication/120117_Conley_ArcticSecurity_Web.pdf ${ }^{54}$ Camilla Sørensen, loc. cit.
} 
in the Arctic could serve as a Trojan horse for Russia's defense activities in the Arctic. ${ }^{55}$ Moreover, the US also cannot be certain whether or not China's presence in the Arctic will turn into a military deployment in the future. The sense of insecurity also contributes to the growing tension between the US and the non-Western powers, especially Russia and China.

Although a primary international legal framework for the Arctic has been provided through several international treaties such as UNCLOS, it is still unable to serve as a forum for addressing security concerns related to increased commercial activity and military presence. ${ }^{56}$ State sovereignty birthed uncertainty in the international anarchical system, forcing states to obtain as much power as possible. Since the US cannot predict what Russia might do in the Arctic region, the country will subsequently always try to ensure its survivability through increasing its power. ${ }^{57}$ The increase of Russia's presence and its military capabilities in the Arctic also raises concern for US officials in terms of losing its power and domination throughout the region. Per the alliance formation theory in balancing behaviour, it explains that once states realize that they cannot materialize national security on their own, they tend to form alliances in an attempt to increase their capabilities to protect themselves from states, coalitions, even other allies whose superior resources could pose a threat and reduce their presence in the region. ${ }^{58}$

NATO is one of the most favorable allies for the US. Besides that five of the eight Arctic states are also member states to NATO, the prominent position of Russia as one of the Alliance's "rival" has subsequently made the United States and NATO allies to respond to Russia's activities on many fronts, including the construction of new icebreakers, improvements to US Navy's Second Fleet, and renovating and making use of Keflavik facilities. ${ }^{59}$ As Russia and other powers such as China continue to escalate their presence within the Arctic, further regional security concerns will arise, fueling states in the Arctic to take measures in an effort to counter said concerns. The NATO alliance is believed to be able to help defend the Arctic's security and stability, especially due to the increasing role of countries such as Russia and China, as well as the inability of the United States (or any other country for that matter) to protect all of the Arctic alone - making inter-alliance cooperation preeminent in times to come. ${ }^{60}$

From the historical perspective since the end of the Cold War, Russian security has been shaped by its vulnerability to invasion, resulting in centuries of expansion and the creation of buffer zones to slow or deter aggressors. ${ }^{61}$ This is where NATO comes in. Geographically, Russia understands that the US has a defensive advantage through its treaty and commitments to NATO, which created a perception of the US as a pervasive threat beyond the North American continent, which is the Arctic region. In general, Russia viewed NATO as a threat to its national peace and security based on NATO's overall actions that have been done towards Russia. ${ }^{62}$ It is frequently incited by Russian officials that NATO is another major threat to Russia's security. As for an example in

\footnotetext{
${ }^{55}$ Conley, loc. cit.

${ }^{56}$ Ibid.

${ }^{57}$ Ibid.

${ }^{58}$ K. N. Waltz, loc. cit.

${ }^{59}$ Marc Lanteigne, "The changing shape of Arctic security," NATO Review, loc.cit.

${ }^{60}$ Tyler Cross, "The NATO Alliance's Role in Arctic Security," The Maritime Executive, July 19th, 2019,

https://www.maritime-executive.com/editorials/the-nato-alliance-s-role-in-arctic-security

${ }^{61} \mathrm{~K}$. N. Waltz, loc. cit.

${ }^{62}$ Stephen Kotkin, "Russia's Perpetual Geopolitics: Putin Returns to the Historical Pattern," Foreign Affairs 95, no. 3 (2016):

2-9, https://www.jstor.org/stable/43946851.
} 
2007, Putin asserted that NATO's expansion was a serious provocative action that "reduced the level of mutual trust" between Russia and NATO. ${ }^{63}$

For example, NATO's expansion in the eastward (Ukraine), installment of ballistic missile defenses in Europe, invading Iraq, as well as abrogating the ABM treaty by the US, can be perceived as a threat to Russia's vital security interest, which drove insecurity to attempt the reestablishment of secured perimeters. This notion also derives from American and NATO superiority in conventional weaponry, which led Moscow to stress its nuclear and retaliatory capabilities to deter it. Moscow's nuclear programs are designed to counter American and NATO superiority in conventional weaponry and reflect a fear of U.S. technological capabilities. ${ }^{64}$

By the mid-2000s, Russian discourse had shifted and considered NATO as an enemy. Russian military doctrines in 2010 and 2014 also identified it as an act towards NATO's military build-up and the expansion of the alliance toward the Russian border, which is considered as the main external military threat to Russia. ${ }^{65}$ Therefore, it can be concluded that being allies with NATO is seen by Russia as a huge advantage for the US, which is asymmetrical for Russia and threatens its peace and security. The enlargement of NATO, supported by the European Union's absorption of most Eastern European countries, subsequently weakened Moscow's position in Europe by promoting stronger, democratic states allied with the West. Weak and dysfunctional states along Russia's periphery provide opportunities for Russia to exert influence. The dramatic decrease in US troops stationed in Europe and the deterioration of European defense capabilities in the two decades after the end of the Cold War contradict Putin's claims of an arms race directed against Russia. ${ }^{66}$ To strengthen its positions in the Arctic, the US should pay closer attention to NATO, which was perceived in the Kremlin as a genuine security threat that required a more assertive posture from Russia. ${ }^{67}$

NATO adopted a whole series of measures in its security, including for the Arctic, and there are two that stand out the most. First is the adoption of the Readiness Action Plan (RAP) that encompasses military steps to enhance the deterrent value of NATO's military posture on the border, and the second is the aim to spend $2 \%$ of their respective gross domestic products (GDP) on NATO's defense within a decade. ${ }^{68}$ However, for as long as NATO has existed, the US has spent a higher proportion in every aspect than its allies, including the implementation of $2 \%$ GDP spending. ${ }^{69}$ The lack of capacity among member states to increase defense budgets is not the only factor that leads to doubt of the effectiveness of NATO from the US. The biggest concern comes from the fact that many NATO countries agreed that the $2 \%$ pledge in Wales, but have no real intention to make good on the promise. Initial budget decisions made around or after the Wales summit and even public announcements by many member states seem to indicate that the political will to reach $2 \%$ is indeed underdeveloped across NATO. ${ }^{70}$

\footnotetext{
${ }^{63}$ Ibid.

${ }^{64}$ Vladimir Putin, "Meeting of the Valdai International Discussion Club," President of Russia, October 18th, 2018, http://en.kremlin.ru/events/president/news/58848.

65 "The Military Doctrine of the Russian Federation," February 5th, 2010, https://carnegieendowment.org/files/2010russia_military_doctrine.pdf

${ }^{66}$ Andrei P. Tsygankov, "The Sources of Russia's Fear of NATO," Communist and Post-Communist Studies 51, No. 2 (2018), https://doi.org/10.1016/j.postcomstud.2018.04.002.

${ }^{67}$ Andrei P. Tsygankov, loc. cit.

${ }^{68}$ Conley, loc. cit.

${ }^{69}$ Mikkel Runge Olesen, "Donald Trump and the Battle of the Two Percent," Danish Institute for International Studies, October 20th, 2020, https://www.diis.dk/en/research/donald-trump-and-the-battle-of-the-two-percent

${ }^{70}$ Jan Techau, The Politics of 2 Percent: NATO and the Security Vacuum in Europe," Carnegie Europe (2015), https://carnegieendowment.org/files/CP_252_Techau_NATO_Final.pdf
} 
The failure of the fulfillment of 2\% GDP for NATO's defense spending by most of NATO's member states, however, shouldn't stop the US from supporting its contribution towards the Arctic because of Russia's increasing presence and capabilities in the Arctic. The alignment of the US and NATO's member states has a great potential to reduce the presence and the domination of Russia in the Arctic. The Arctic has always remained a vital strategic region for Euro-Atlantic security. Five of the Arctic Council's members are also part of NATO, which are: Canada, Denmark, Iceland, Norway, and the United States. NATO Allies also have conflicting views about Russia's intentions in the Arctic and increasing military presence in the region and have reached a consensus on the importance of the region to NATO security. Moreover, although there is no formal role of NATO in the Arctic, the Alliance has reaffirmed its willingness to improve security at all of its borders, including in the North Atlantic at the Warsaw Summit in July 2016.

The communiqué of the 2016 Warsaw Summit acknowledged evolving security challenges in the North Atlantic, particularly regarding NATO-Russia relations. The alliance considered Russia's aggressive actions, which include provocative military activities in the periphery of NATO territory, and emphasized deterrence as well as the need to strengthen NATO's defense posture. At Warsaw, NATO Allies also agreed to enhance the Alliance's situational awareness in the North Atlantic in response to Russia's military presence. It is worthwhile noting that the North Atlantic is bordering the Arctic; therefore, any change in the security of the former is likely to have an impact on the High North as well. Thus, it becomes important for NATO Allies to increase situational awareness in the Arctic as well. ${ }^{71}$

When states are confronted with emerging challenges, they either turn to existing international organizations and governing norms or create new organizational structures to respond. ${ }^{72}$ However, the exclusion of Russia from NATO, with the exception of the NATO-Russia Council, presents a fundamental dilemma that NATO's role in the Arctic can be muted. But for the US, NATO can be considered as central to their general defense and security strategies to fulfill its national security priorities in the Arctic. ${ }^{73}$ Therefore, The US can increase its presence as the great power in the Arctic, backed up by NATO, which is perceived by Russia as a big threat to its security.

The fact that five out of the seven Arctic States (aside from Russia) are the members of NATO, and the other two (Finland and Sweden) are NATO enhanced opportunities partners, it is believed that the allies created between the US and NATO are more likely to have bigger power to control the Arctic compared to Russia. Following the hegemonic stability theory, great powers tend to seek domination over all parts of the international system in every aspect, and that can be seen through Russia and the US presence in the Arctic. ${ }^{74}$ As two of the most powerful states in the Arctic, Russia and the US are trying to maximize their capability in the Arctic to show their domination in the international realm and seek status as a hegemonic power. The US domination in NATO in this sense gives a higher possibility for the two to cooperate to suppress Russia's domination, especially when most of NATO's member states also share the same perspective and sees Russia as a threat to their stability in the Arctic. Therefore, if the cooperation of the US with NATO can deter Russia's presenc e

\footnotetext{
${ }^{71}$ David Auerswald, "NATO in the Arctic: Keep its role limited, for now," War on the Rocks, October 12th, 2020 https://warontherocks.com/2020/10/nato-in-the-arctic-keep-its-role-limited-fornow/\#: :text=Nevertheless $\% 2 \mathrm{C} \% 20$ individual $\% 20$ NATO $\% 20$ members $\% 20$ with,to $\% 20$ advance $\% 20$ their $\% 20$ Arctic $\% 20$ inter ests

${ }^{72}$ Conley, loc. cit.

${ }^{73}$ Ibid.

${ }^{74}$ Steve Smith, Amelia Hadfield, and Tim Dunne, loc. cit.
} 
and increasing capabilities in the Arctic, the US is likely to be a dominant state that can create hegemonic stability in the Arctic.

\section{Conclusion}

A more open and accessible Arctic is in place due to the melting of ice in the region. Due to its enormous potential as one of the world's greatest untapped natural resources reserves and strategic sea routes, the Arctic has become increasingly important to surrounding states, including the US and Russia, the two major powers within the region. Furthermore, a non-Arctic country, China, has also shown interest to pursue their economic interests that lie up in the North. Despite being rather inactive in the last few decades, the territorial claims followed by a more accessible Arctic has led the US to pursue a more active policy within the region. The clash of interests of the US and other states, especially Russia and China in the region has developed into tension and insecurity.

Hence, in order for the US to pursue their national interests, it is important for them to balance the power and threat coming from Russia and China through rebuilding its alliance with NATO countries, especially those within the Arctic Council. Aside from the fact that NATO has major advantages in terms of weaponry, the US also needs to maintain its influence within the region. Although several NATO countries have yet to succeed in contributing $2 \%$ of their GDPs in their defense spending, it is important to note that the US has bigger concerns in the Arctic. Hence, it can be understood that the US needs NATO, as the US has deep interests to pursue in the Arctic that are difficult to maintain if the US does not have a strong alliance due to the presence of two strong nonWestern powers, Russia and China.

Seeing that the relationship of the US with NATO has previously been strained under the Trump Administration, the writers of this paper would like to recommend the Joe Biden Administration to make amends and rebuild bonds with NATO countries. The existing security circumstances that are faced by the US in the Arctic are too costly for the US to compromise. Thus, tolerating the lack of success of several NATO countries in fulfilling the $2 \%$ requirement of defense spending should be done by the US to mitigate more complex loss and insecurity. As the US is the biggest contributor within NATO itself, it will be easier for them to pursue their interests in the Arctic through NATO, as they have established influence within the alliance. 


\section{Bibliography}

(2008). Russian Federation's Policy for the Arctic to 2020. KOARC. http://koarc.org/theme/northpn_ko/03/pdf/rusia_eng.pdf

(2010). The Military Doctrine of the Russian Federation. https://carnegieendowment.org/files/2010russia_military_doctrine.pdf

(2018). China's Arctic Policy. The State Council Information Office of the People's Republic of China, http://english.www.gov.cn/archive/white_paper/2018/01/26/content_281476026660336.htm

(2018). Meeting of the Valdai International Discussion Club. President of Russia. http://en.kremlin.ru/events/president/news/58848.

(2021). Biden says U.S. commitment to NATO is 'unshakeable'. Reuters. https://www.reuters.com/article/us-g7-meeting-biden-munich-idUSKBN2AJ1ZT

(n.d.). Why NATO Matters. U.S. Mission to the North Atlantic Organization. https://nato.usmission.gov/our-relationship/why-nato-matters/

Auerswald, D.. (2020). NATO in the Arctic: Keep its role limited, for now. War on the Rocks. https://warontherocks.com/2020/10/nato-in-the-arctic-keep-its-role-limited-fornow/\#: : text=Nevertheless\%2C\%20individual\%20NATO\%20members\%20with,to\%20advance\% 20their\%20Arctic\%20interests

Beauvais, S. D.. (2015). “Map Room Arctic Militarization.” World Policy. http://worldpolicy.org/wpcontent/uploads/2015/06/Summer15_16-17_MapRoom.pdf

Browne, R.. (2019). NATO report says only 7 members are meeting defense spending targets. $C N N$. https://edition.cnn.com/2019/03/14/politics/nato-defense-spending-target/index.html

Caiyu, L.. (2018). China's role in Arctic governance cannot be ignored. Global Times. https://www.globaltimes.cn/content/1128626.shtml

Cammarata, S.. (2020). U.S. reopens consulate in Greenland amid White House's Arctic push. Politico. https://www.politico.com/news/2020/06/10/us-reopens-greenland-consulate-310885

Committee on the Assessment of U.S. Coast Guard Polar Icebreaker Roles and Future Needs. (2007). Polar Icebreakers in a Changing World: An Assessment of U.S. Needs. (Washington: The National Academies Press). https://www.nap.edu/read/11753/chapter/5\#21

Conley, H. A.. (2012). A New Security Architecture for the Arctic: An American Perspective. $A$ report of the CSIS Europe Program. https://csis-website-prod.s3.amazonaws.com/s3fspublic/legacy_files/files/publication/120117_Conley_ArcticSecurity_Web.pdf

Cross, Tyler. (2019). The NATO Alliance's Role in Arctic Security. The Maritime Executive. https://www.maritime-executive.com/editorials/the-nato-alliance-s-role-in-arctic-security

Dagi, D.. (2018) Balance of Power of Balance of Threats: Revisiting Ottoman Alliance Politics before the Great War. Open Political Sciences, pp. 144 
36 Bernadeth Franchika, Sharon Sebastian Effendy, Vanessa Anthea| NATO in The Very Cold War: Why the US Needs NATO in the Arctic

De Neve P. A., et.al. (2015). Security of the Arctic. Belfer Center for Science and International Affairs.

https://www.belfercenter.org/sites/default/files/legacy/files/Arctic\%20Security\%20Policy\%20Brie f.pdf

Dunne, T., et.al. (2013). International Relations Theories. USA: Oxford University Press.

Eiterjord, T. A.. (2019). China's Busy Year in the Arctic. The Diplomat. https://thediplomat.com/2019/01/chinas-busy-year-in-the-arctic/

Gady, F.. (2018). China Launches First Domestically Built Polar Icebreaker. The Diplomat. https://thediplomat.com/2018/09/china-launches-first-domestically-built-polar-icebreaker/

Gautier, D. L.. (2011). U.S. Geological Survey Circum - Arctic Resource Appraisal. OTC Arctic Technology Conference, https://doi.org/10.4043/22061-MS

Goldstein, L.. (2020). Washington should chill out over Russia's Arctic ambitions. Defense News. https://www.defensenews.com/opinion/commentary/2020/11/13/reflecting-on-future-us-russiarelations-through-the-lens-of-the-high-north/

Golts, A.. (2011). The Arctic: A Clash of Interests or Clash of Ambitions? Russia in the Arctic, ed. Stephen J. Blank, Carlisle, Pa.: Strategic Studies Institute, U.S. Army War College, pp. 59

Greaves, W.. (2016). Thinking Critically About Security and the Arctic in the Anthropocene. The Arctic Institute. https://www.thearcticinstitute.org/thinking-critically-security-arctic-anthropocene/

Guzzini, S. (1998). Realism in International Relations and International Political Economy. London: Routledge.

Heininen, L., et.al. (2014). Russian Strategies in the Arctic: Avoiding a New Cold War. Valdai Discussion Club. https://www.uarctic.org/media/857300/arctic_eng.pdf

Hughes, C. W. and Ming, L. Y.. (2011). Security Studies: A Reader. New York: Routledge.

Isachenkov, V.. (2013). New Russian nuclear sun enters service. Navy Times. http://www.navytimes.com/news/2013/01/ap-russia-says-new-sub-enters-service-011013/.

Jackson, R. and Sorensen, G.. (2013). Introduction to International Relations: Theories and Approaches. United Kingdom: Oxford University Press

Kotkin, S.. (2016). Russia's Perpetual Geopolitics: Putin Returns to the Historical Pattern. Foreign Affairs. https://www.jstor.org/stable/43946851

Lanteigne, M.. (2019). The Changing Shape or Arctic Security. NATO Review. https://www.nato.int/docu/review/articles/2019/06/28/the-changing-shape-of-arcticsecurity/index.html

Lanteigne, M.. (2020). The Twists and Turns of the Polar Silk Road. Over the Circle. https://overthecircle.com/2020/03/15/the-twists-and-turns-of-the-polar-silk-road/

Lino, M.. (2020). Understanding China's Arctic activities. IISS. https://www.iiss.org/blogs/analysis/2020/02/china-arctic

McCarthy, N.. (2019). NATO Summit: The Countries Meeting The 2\% Threshold. Forbes. 
37 Bernadeth Franchika, Sharon Sebastian Effendy, Vanessa Anthea| NATO in The Very Cold War: Why the US Needs NATO in the Arctic

https://www.forbes.com/sites/niallmccarthy/2019/12/03/nato-summit-the-countries-meeting-the-2threshold-infographic/?sh=3e6c21161f2c

Northam, J.. (2011). Clinton, Russia Spar Over Missile Defense System. NRP. http://www.npr.org/2011/12/08/143386914/clinton-russia-spar-over-missile-defense-system.

Olesen, M.R.. (2020). Donald Trump and the Battle of the Two Percent. Danish Institute for International Studies. https://www.diis.dk/en/research/donald-trump-and-the-battle-of-the-twopercent

Smith, S. et.al. (2016). Foreign Policy: Theories, Actors, Cases. Oxford: Oxford University Press.

Sorensen, C.. (2019). Intensifying U.S.-China security dilemma dynamics play out in the Arctic: Implications for China's Arctic strategy. Arctic Yearbook.

Techau, J.. (2015). The Politics of 2 Percent: NATO and the Security Vacuum in Europe. Carnegie Europe. https://carnegieendowment.org/files/CP_252_Techau_NATO_Final.pdf

Tsygankov, A.P.. (2018). The Sources of Russia's Fear of NATO. Communist and Post-Communist Studies. https://doi.org/10.1016/j.postcomstud.2018.04.002

Upton, G.. (2019). Great Power Problems: Russia Wants Control over the Arctic Region. The National Interest. $\quad \mathrm{https} / /$ nationalinterest.org/feature/great-power-problems-russia-wants-control-overarctic-region-54227

Walt, Stephen M. (1985). Alliance Formation and the Balance of World Power. International Security 9 (4), pp. 3-43. https://doi.org/10.2307/2538540

Waltz, K. N.. (1979). Theory of International Politics. Reading, Mass.

Webb, M. and Krasner, S.. (1989). Hegemonic Stability Theory: An Empirical Assessment, Review of International Studies 15 (2), pp. 183-198.

Wemer, D.. (2018). Here's Why the United States needs NATO," Atlantic Council, https://www.atlanticcouncil.org/blogs/new-atlanticist/here-s-why-the-united-states-needs-nato/

Woody, C.. (2020). The US Navy is learning how to operate in the Arctic, and more ships may not be the answer. Business Insider. https://www.businessinsider.com/us-military-presence-in-arcticchallenged-by-harsh-conditions-2020-2? $\mathrm{r}=\mathrm{US} \& \mathrm{IR}=\mathrm{T}$ 